\title{
Putting Hell First: \\ Cruelty, Historicism, and the Missing Moral Theory of Damnation
}

\begin{abstract}
Recent work on the morality of hell spans the various subdisciplines of theology, with one ironic exception. There is no consideration specifically from the perspective of theological ethics. Including such a perspective reminds us that what God does in hell is intentionally cruel unless it can be shown to be good or just according to some moral theory of punishment. An adequate defence of hell requires a positive account of how God's acting to eternally torment some humans is beautiful, just, and worthy of worship. This suggests a short-term and long-term task. The short-term task, which this article pursues, tests whether an adequate moral theory is available. It evaluates three possible candidates, tied together by their view that historical location either helps (or misleads) our evaluation of hell's justice. The third of these three is the most interesting, as it offers a historicist defence of hell: we mistakenly believe hell is cruel only because of aversions to cruel and unusual punishment that emerged in modernity. Nonetheless, these three defences are inadequate, necessitating a longer-term goal: we either need better moral theories or better accounts of hell. We also need much greater analytic clarity regarding theological statements of the form, I want doctrine y to be true but believe doctrine $x$ is true.
\end{abstract}

keywords: hell, universalism, ethics, punishment, voluntarism, cruelty, Anselm, history

When the film of The Da Vinci Code was released, one of its surprise critics was New Testament scholar Bart Ehrman. This was surprising because Ehrman's view of the early church is pretty similar to that depicted in Dan Brown's novel. Why would he not see Brown as an ally? The problem was that The Da Vinci Code, by advocating Ehrman's views with little seriousness, risked turning them into a joke. Yes, the two authors have some similar ideas, but therein lies the problem. However fun Brown's novel is to read on a beach holiday, if that's what Ehrman's position amounts to, he knows that few will buy it. He doesn't want his scholarship to stand or fall on the merits of some smooth and fashionable popular alternative.

This, I think, must have been what Christian universalists felt when reading Rob Bell's Love Wins. Not that Love Wins is as laughable as Da Vinci; it's not. Parts of it are good, but most of it is irrelevant filler and almost all of it has been said better elsewhere. What Bell's and Brown's books have in common is that they oversimplify real debates. The leading voices in those debates, while they might appreciate the attention generated, have reason to complain.

Christian universalists like Thomas Talbott, Tom Greggs, and Robin Parry — not to mention those open to rethinking some aspects of the traditional doctrine of hell, including Balthasar, Barth, and C.S. Lewis - do not deserve to be painted with the same brush as Bell. The problem with Love Wins is simply that Bell joins an important and exciting conversation ignoring that it was underway long before he got to the party. The unfortunate effect is to obscure the hard work of those who held their tongue through years of patient reading, and worse still, to prompt new conversations on the entirely wrong track.

This means that Bell's critics, who have started those new conversations, have no cause to be proud. When a negative review of Love Wins was posted on the Internet (by someone who admitted to not reading the whole book), it prompted the usually grown-up John Piper to post a gleeful 'Farewell, Rob Bell' to his 180,000 Twitter followers. Albert Mohler, president of Southern Baptist Theological Seminary, threw together a 'panel' days after the book's release, though only critics of Bell were included. (If everyone agrees, that's not a panel; it's a sermon with three preachers.) At least a dozen quick-to-press book responses appeared more or less instantaneously, many with childish titles like Get the Hell Out of Here? and, invoking Piper's tweet, Farewell Rob Bell, complete with a cartoon cover of Bell furiously paddling a lifeboat toward (or away from?) a cruise ship named Orthodoxy. 
The great shame of all of this is that the real conversation, the one worth having, is lost along the way. I hope to facilitate that conversation. My approach begins from the following observation: much of the recent discussion of hell and universalism is sequestered between four theological methodologies: biblical studies, systematic theology, church history, and philosophy of religion. An example of the first is The Evangelical Universalist by Robin Parry (writing under the pseudonym Gregory MacDonald), for whom the debate is chiefly about whether universalism can be made compatible with evangelical habits of scriptural study. Examples of discussions from systematic theology include debates about the logic of election and the implications of that doctrine for the afterlife. Predictably, Barth and Augustine are prominent here, as invoked (toward differing conclusions) by, for example, Greggs and Oliver Crisp. Historical treatments have not been as prominent in the most recent conversations, but I have in mind efforts to portray universalism as a valid 'minority report' in the tradition, and thus within the scope of historic orthodoxy. Greggs fits here too, with his Barthian recovery of Origen, as well as the recent collection, All Shall Be Well. ${ }^{1}$ To these we can add work within philosophy of religion, such as that by Marilyn McCord Adams, Jerry Walls, and Jonathan Kvanvig. These by no means exhaust the discussion, but this is enough to show what is missing: there is no consideration specifically from the perspective of theological ethics. This should surprise us.

As an ethicist, when I read debates about hell and universalism, I feel as though I ought to be on home territory. It turns on concepts that are the staple of my field: justice and mercy, goodness, rights, virtue, happiness and flourishing, punishment, judgment, cruelty, despair, and torture. All of these are moral matters. Granted, an ethically-centred response will not put the matter to rest on its own, any more than the others could on their own. But a perspective rooted in theological ethics can help elucidate some confused areas of the debate. Conceding the possibility of disciplinary bias ('Of course the ethicist thinks it's about ethics!'), some facets of this debate do require sustained attention to moral concepts as such, including the histories of those concepts as they have reached us via law, theology, and philosophy.

I explain my thesis in more detail below, but put briefly: I know of no Christian moral theory under which the traditional Augustinian view of hell can plausibly be seen as good or just. In the long run, this means we either need better moral theories or better conceptions of hell. In the short run, it means we ought to evaluate defences of hell that would refute my claim. It is this short-term task that I pursue in these pages: I consider, and find unsatisfactory, a number of attempts to show that a traditional Augustinian conception hell is morally good. What unites these attempts is the place they give history in explaining why we usually find hell unjust. They do this either by downplaying historical context or emphasizing history to a point that borders on historicism. Because historicism is theologically and philosophically interesting, this defence deserves particular attention.

\section{A New Universalism? A Weakened Hell?}

Until the publication of Bell's book, the most lively, recent discussion of hell in academic theology was (with a few exceptions) limited to a fairly narrow scope, often revolving around Thomas Talbott's The Inescapable Love of God and various articles he published from 1983 to 1997. At its heart, Talbott's is a personal struggle to vindicate God's goodness in light of the seeming injustice of a loving father torturing his children for eternity. In the opening chapters of the book he writes, 'I knew instinctively that I could never worship a God who is less kind, less merciful, less loving than my own parents, but that is just what I seemed to encounter in the mainstream of Western theology.'

\footnotetext{
${ }^{1}$ Gregory MacDonald, ed. All Shall Be Well: Explorations in Universalism and Christian Theology from Origen to Moltmann (Cambridge: James Clarke, 2011).

2 Thomas Talbott, The Inescapable Love of God (Universal Publishers, 1999), 8.
} 
Talbott's project has been taken up in the past decade by Robin Parry, who gives it two twists. Parry seeks to bring the discussion within evangelicalism, especially evangelical approaches to the Bible, and (via a recent collection of essays) makes a case for it as a legitimate minority report throughout church history. Taking a stronger view than those who merely hope all will be saved, Parry is a 'hopeful dogmatic universalist.' ${ }^{3}$ Despite the two twists, he shares Talbott's starting point. His universalism emerges from a personal crisis of worship.

There is no formal movement or group of New Universalists (a term that I have invented), but it is nonetheless a helpful designation and applies chiefly to Talbott and Parry, but derivatively to those who are sympathetic but might differ on some points, such as Tom Greggs. In fact, Greggs can help us see further what is new about the New Universalism. The first characteristic is the focus on it as a Christian conviction, rather than emerging from interreligious dialog, as with John Hick. The second can be seen in Gregg's concern that universalism not become a formal doctrine or principle of the church. This is both to preserve God's freedom and for the sake of continuity with the church's teaching throughout history. ${ }^{4}$ Thus the New Universalists want to go beyond hoping that all are saved, but seemingly not so far as saying that universalism is dogma. In fact, Parry now uses the adjective 'convinced' rather than 'dogmatic' universalist, precisely to avoid confusion on this matter. ${ }^{5}$

Two sustained studies of hell, both engaging Talbott's New Universalism, are Jerry Walls's Hell: The Logic of Damnation and Jerry Kvanvig's The Problem of Hell. Both are presented as defences of hell against universalism, but importantly, both 'weaken' the traditional Augustinian conception of it. Walls does so by emphasizing human freedom: hell is the sort of place one can coherently put oneself. Kvanvig's view essentially combines a temporary hell with annihilation. ${ }^{6}$ A similar phenomenon can be seen in recent Roman Catholic theology. For example, John Finnis purports to critique Balthasar's Dare We Hope that All May Be Saved? but what emerges is something very much like Walls's view, in which the penal aspects of hell are replaced by hell-as-natural consequence. ${ }^{7}$

This reveals that there is a two-way weakening, one that can be seen on both sides of this debate. New Universalism is weaker than earlier conceptions by being less than a dogma and also by backing off from the liberal confidence that everyone is saved because all religions pretty much amount to the same thing anyway. But the defence of hell is correspondingly weakened, because hell's defenders respond not by reasserting an Augustinian hell but by showing that universalism can be false without entailing hell's most morally troubling features.

What's missing here are defences that reject this weakening, so that is what I examine below. This stronger view, which I have been calling Augustinian, is not in fact peculiar to Augustine; it is shared in most respects by Thomas Aquinas, John Calvin, and others. ${ }^{8}$ It is characterized by four features in particular, and when I refer to hell in what follows, this is the sort of hell I have in mind. ${ }^{9}$ An Augustinian hell is:

\footnotetext{
${ }^{3}$ Gregory MacDonald, The Evangelical Universalist: The Biblical Hope That God's Love Will Save Us All, 2nd ed. (London: SPCK, 2012), 4, emphasis added.

${ }^{4}$ Specifically, Greggs is sensitive to the fact that Origen was condemned for holding to something like universalism (though whether the anathemas were directed at his universalism in particular is much debated).

${ }^{5}$ MacDonald, All Shall Be Well: Explorations in Universalism and Christian Theology from Origen to Moltmann, 12n22.

${ }^{6}$ Jonathan Kvanvig, The Problem of Hell (New York: Oxford University Press, 1993); Jerry Walls, Hell: The Logic of Damnation (Notre Dame: University of Notre Dame Press, 1992).

${ }^{7}$ John Finnis, 'Hell and Hope,' in Religion and Public Reasons: Collected Essays Volume V (Oxford: Oxford University Press, 2011), 370.

${ }^{8}$ Jerry Walls, 'Heaven and Hell,' in The Oxford Handbook of Philosophical Theology, ed. Michael Rea (Oxford: Oxford University Press, 2009), 494.

${ }^{9}$ Hunsinger invokes a similar concept, also drawn from Augustine, which he calls 'the strong view of hell', defined by seven components. George Hunsinger, 'Hellfire and Damnation: Four Ancient and Modern Views,' Scottish Journal of Theology 51, no. 4 (1998): 410-414.
} 
- double predestined (not merely where one chooses to go or is allowed to go),

- unending (no annihilation),

- a place of conscious torment (torture), and

- penal (not a natural consequence of $\sin$ in the way that a hangover is a consequence of drunkenness; rather it is an extrinsic punishment imposed by a judge).

When I wrote above that I know of no Christian moral theory under which hell can be seen as good or just, it is these features that I have in mind. What unites them is that they are focused on God's active involvement and moral agency. Hell is what it is because: God sends people there, God miraculously sustains their existence, God wills the pain that they experience there, and God deliberately attaches sanctions to wrongdoing. These qualities make God intentionally cruel unless they can be shown to be good or just according to some theory of punishment (specifically) and within a broader account of justice (generally).

\section{The Invention of Cruelty}

This in turn raises a specific moral challenge for those who would defend the traditional doctrine. An adequate defence would require a positive account of how God's acting to eternally torment some humans is beautiful, just, and worthy of worship. If eternal punishment is an act of God, it must be - like all of God's acts - worthy of praise and honour.

This demand for an account of the goodness of God's damning is hardly new. Meeting the objection is clearly Anselm's goal in parts of Cur Deus Homo, and Augustine himself seeks to persuade 'those compassionate Christians' who doubt that an eternal hell would be just. ${ }^{10}$ So theologians throughout history recognize that some-Augustine says 'very many' - perceive hell as neither good nor worthy of honour. ${ }^{11}$ From the church's earliest days, some have held that the fate of sinners could not really be so bad as Jesus seems to suggest. ${ }^{12}$ This sentiment received full sympathy even from hell's most forceful defenders, though most do eventually conclude, with Augustine, that once we've got our facts straight we'll see that compassion for the damned is perverse. ${ }^{13}$ Nonetheless, Augustine's description of his too-compassionate opponents makes them sound almost exactly like the New Universalists. ${ }^{14}$ So their challenge is not new.

What is new in the recent debates, however, is a specific historicized account from hell's defenders of why hell appears unjust. How do we explain our inability to perceive hell's justice in light of our place in history?

Before turning to hell's defenders, I begin with a non-religious critic. Judith Shklar's influential essay 'Putting Cruelty First' - to which my own title is an allusion-argues that the great achievement of Western liberalism and humanism is in coming to see cruelty as the summum malum, the greatest evil. She is not arguing that cruelty is an especially religious problem-Machiavelli was both non-religious and cruel - but she does doubt that the true believer can ultimately and entirely reject cruelty, in the way that the modern liberal ought. 'To hate cruelty with the utmost intensity is perfectly compatible with biblical religiosity, but to put it first does place one unalterably outside the sphere of revealed religion.' ${ }^{15}$

She begins her study by noting that cruelty has been little studied in philosophy. Aristotle doesn't mention it, it's not among the seven deadly sins, and Augustine is far more concerned with pride than cruelty. 'If one really wants to know what cruelty looks like, one can, of course, look at Giotto's Last Judgment, where every conceivable instrument of physical

\footnotetext{
${ }^{10}$ Augustine, City of God, trans. Henry Bettenson (London: Penguin, 1972), 21.17.

${ }^{11}$ Augustine, Enchiridion, trans. Albert Outler (Philadelphia: Westminster Press, 1955), 112.

${ }^{12}$ Finnis, 'Hell and Hope,' 368.

13 Augustine, City of God, 21.24.

${ }^{14}$ Augustine, City of God, 21.17-18. Augustine, Enchiridion, 112.

15 Judith Shklar, Ordinary Vices (Cambridge, MA: Belknap Press, 1984), 8.
} 
torture is used against the damned. ${ }^{16}$ Hell, then, is the paradigmatic picture of cruelty. Giotto's fresco does indeed make its viewers squirm, though Shklar herself spares us the gritty details. It is nothing if not gritty. Many of the damned are tormented specifically on their sexual organs: monks have their penises ripped with tongs or gnawed by demons; a woman is hanged from a hook in her vagina. Lucifer eats the damned and then excretes them whole (we see one unfortunate man making the exit). ${ }^{17}$ Shklar's point is that part of what it means to be liberal or humanitarian is to have a central or overriding aversion to that sort of thing and to name it cruel.

Her argument is that in order to be combatted, cruelty, as a concept, needed to be invented or discovered, and that rejecting a traditional hell was an important step in cruelty's discovery. 'Certainly those Christians who came to doubt the literal accounts of physical torment in hell also worried about the cruelty and vindictiveness ascribed to God. By the eighteenth century these were very common concerns, especially in England, where secular humanitarianism had begun its extraordinary career. ${ }^{18}$ Thus Shklar dares her readers, can you look on the Last Judgment and call it good? Can you look at hell and worship?

What makes Shklar's account so interesting is that recent defences, especially in response to the New Universalists, follow almost the exact same logic, but to the opposite conclusion. Like Shklar, they provide historicist accounts of hell's decline. In what follows, I will consider three defences. Each of these takes the form, 'I realize that hell seems unjust, but that's only because of $x$.'

There are significant problems with each of the three. Thus we are left with the problems that these explanations had sought to avoid: an inability to perceive the goodness of God's acting in hell. We cannot see the truth in what Dante says is inscribed on the gates of hell: 'Justice inspired my exalted Creator: I am a creature of the Holiest Power, of Wisdom in the Highest and of Primal Love.' ${ }^{19}$

\section{Hell Seems Cruel Because: It Just Does}

What looks cruel or unjust to me might be due to my historical context, my sinful selfishness, or simply my being human. This is captured well by Luther's remark on the hardening of Pharaoh's heart, 'it is not for us to inquire into these mysteries, but to adore them... What God wills is not right because he ought or was bound so to will; on the contrary, what takes place must be right, because he so wills'. ${ }^{20}$ Applied to our debate: if hell seems contrary to your conception of justice, so much the worse for your conception of justice.

I here label this simply voluntarism, though I actual have in mind a particular species of voluntarism, which combines the assertion that justice is found in God's will with scepticism about human's ability to rationally comprehend that will. ${ }^{21}$

There are significant problems with voluntarism as a moral theory, though one can see the appeal it holds within (especially) Reformed systematic theology because it protects God's sovereignty. These issues would take many books to address, so here I will limit myself to one observation. On the most general level, Luther proposes that we respond to mystery with worship. Such advice has a long and rich history in Christian devotion. But on a more

\footnotetext{
${ }^{16}$ Shklar, Ordinary Vices, 7.

${ }^{17}$ Medieval and renaissance artists were allowed to depict hell so vividly and imaginatively because it is not as clearly depicted in the Bible as, say, the nativity or crucifixion. Thus they did not risk violating an authoritative definition of it. Brendan Cassidy, 'Laughing with Giotto at Sinners in Hell,' Viator 35(2004): 356.

${ }^{18}$ Shklar, Ordinary Vices, 7.

${ }^{19}$ Dante, Inferno, trans. Robin Kirkpatrick (2006), 3:4-6.

${ }^{20}$ Quoted in J.B. Schneewind, The Invention of Autonomy: A History of Modern Moral Philosophy (Cambridge: Cambridge University Press, 1998), 30-31, emphasis added.

${ }^{21}$ The two don't always go together, as they don't in John Hare's divine command theory. Partly this shows that the voluntarist-intellectualist dichotomy is not as simple as often portrayed. See John Hare, God's Call: Moral Realism, God's Commands, and Human Autonomy (Grand Rapids: Eerdmans, 2001).
} 
particular level, what Luther proposes is both psychologically impossible and theologically illadvised. If I cannot perceive the goodness of one of God's acts, I might suspend judgment on it, but I could not adore it. I could not ascribe worth or goodness to it. And if I said that I was both worshiping God's goodness in punishing and (at the same time) unable to perceive God's goodness in punishing, then we should conclude that I am confused or duplicitous.

To be salvaged, the voluntarist needs some principled account of why humans can understand much about God, including his love and goodness, but cannot understand this act as good. Yet that account is precisely what Luther is happy not to supply: it is not for us to inquire, only to adore.

\section{Hell Seems Cruel Because: You Have The Wrong Theory of Justice}

But perhaps, contra Luther's voluntarism, humans can comprehend, and therefore adore, God's acting in hell. Why then does it seem so unjust? Perhaps we could understand God's acting in hell in theory, but in practice we often do not. This is the more common approach to the question throughout church history. The final sections of Augustine's Enchiridion are a good example, striving to justify hell's justice, while not wanting to overconfidently assume it can be entirely figured out. For present purposes, however, the best example is Cur Deus Homo because it illustrates the strategy of downplaying historical context. I shall focus on Anselm's present-day defender, Oliver Crisp.

The particular aspect of hell that Anselm might explain concerns how hell's infinite duration seems to violate principles of retributive justice. Anselm affirms the premise: a punishment must fit the crime. So he grants that it may seem unjust to punish a finite sin (say, stealing a bike) with an eternity of suffering. But this overlooks that, according to Anselm, the severity of a punishment varies according to the social honour of victim. Stealing the king's bike deserves a harsher punishment than stealing the peasant's bike. God is infinitely honourable and worthy of infinite obedience, so even the smallest effacement of his honour is worthy of an infinitely harsh punishment. Refuting this plays an important role in the New Universalist critique of hell, especially Talbott. Talbott points out that we do not, in fact, think that harsher punishment correlates to honour, even if people believed it in Anselm's time (and that may be doubtful). ${ }^{22}$ If anything, a less harsh punishment is due to the thief who steals Steve Jobs's bike (he could easily buy another) than the bike of Jobs's gardener.

In an article-length critique of Talbott, Crisp seeks to defend the Augustinian conception of hell by showing it to be compatible with retributive justice after all, roughly along Anselmian lines. He subtly modifies Anselm, conceding that punishment should not vary according to the victim's worth or dignity, at least not if the victim is human.

Ordinarily, the character of the wrongdoer is considered more important in the assessment of the severity of a crime than the character of the person wronged. But that, I suggest, is because, in such cases, the characters under consideration are of those who belong to the same kind: humans. When a sin is committed against a person who is divine and therefore of a different ontological kind, this means of assessment does not obtain, since the character of the person offended, (the person who is of the kind 'divine') is of infinitely greater worth than the character of the wrongdoer, who belongs to the kind 'non-divine'. The principle at work here is something like this: the dignity of God is infinite, so the seriousness of an offence committed against God is infinite, or infinitely surpasses that of other kinds. ${ }^{23}$

This makes considerably less sense than Anselm's original argument, upon which Crisp is trying to improve. In Anselm, we can at least perceive a reason why worth and dignity play the sort of role they do: he was writing in a context for which civil stability depended on

${ }^{22}$ See Thomas Talbott, 'Punishment, Forgiveness, and Divine Justice,' Religious Studies 29, no. 2 (1993): 158.

${ }^{23}$ Oliver Crisp, 'Divine Retribution: A Defence,' Sophia 42, no. 2 (2003): 40. 
expressing honour through well-defined social roles. That is no longer convincing to us as a principle of justice, because it is tied to contingent aspects of feudal Europe, but we can see why it might have seemed plausible to Anselm. But Crisp simply asserts that sins against beings of a different ontological kind merit different punishments.

Crisp realizes that he seems to owe his readers some sort of explanation, and he toys with providing one. We might, he says, explain why different ontological kinds deserve different kinds of honour by pointing to the properties that distinguish those kinds. For example, why is someone who harms a dog punished less than someone who harms a child? But Crisp flatly refuses to provide such an explanation, on the grounds that it would make something more fundamental than ontology for explaining dignity or worth. Perhaps so, but then at least we would have an explanation. Crisp offers no explanation, only an assertion.

Anselm's view was actually something like the following: we all owe debts all of the time to all sorts of people, depending on our social roles. The lord of the manor owes me, his serf, protection from the Vikings. I owe him two weeks' labour during the harvest. But to God, I owe complete obedience from the moment of my birth, meaning that there's no way to compensate for any disobedience. If I had failed to provide my feudal lord the two weeks of labour that I owe, then I could conceivably put things right with extra labour next harvest. But to God, I already owe all future obedience; there's no way to give extra obedience tomorrow as compensation for my disobedience yesterday. This seems to be what Crisp has in mind, and it makes a certain amount of sense if one accepts Anselm's presuppositions.

What we might first notice about this argument is that its presuppositions are feudal. ${ }^{24}$ But equally important is that they are aesthetic. ${ }^{25}$ So when Anselm writes, as he repeatedly does, of the need for everything to remain in its assigned place, we might automatically think of social class. But he equally has in mind the image of beautiful ordering. The serf's place is not merely a matter of civil order; all ordering is part of God's beautiful design. The serf has his place, but so do the stars in the heavens.

With this in mind we can begin to answer the puzzle that Crisp's appeal to Anselm leaves us with: what is the nature of our insult to God when we sin? The tension arises from two passages in Cur Deus Homo where Anselm speaks in very different terms. In the first, he poses a dilemma. Suppose someone tells me that the world will be destroyed unless I glance in a particular direction, but God tells me not to look in that direction. Anselm concludes, 'this is how gravely we sin whenever we knowingly do something, however small, contrary to the will of God. ${ }^{26}$ Sin is infinitely grave: worse than allowing the destruction of infinite worlds. It seems to be from this passage that readers like Crisp take the idea of sin's infinite gravity. But this is puzzling, because here (indeed, in that entire chapter) Anselm never mentions God's dignity or honour, or civil order or the ordered beauty of the cosmos. These are the hallmarks of his argument throughout the treatise, and here-just when he would seem to need them most - they disappear.

${ }^{24}$ Recent work has challenged the feudal setting of Cur Deus Homo, pointing to various alternatives. Some even complain of a historiographical 'tyranny' asserting feudalism as a construct for interpreting Anselm. Others emphasize the Benedictine roots of Anselm's thought, while still others accept his feudal presuppositions which trying to show their plausibility outside that context. These are helpfully surveyed in David L. Whidden, "The Alleged Feudalism of Anselm's Cur Deus Homo and the Benedictine Concepts of Obedience, Honor, and Order," Nova et Vetera 9:4 (2011): 1055-87. I am therefore going somewhat against the grain of recent scholarship in returning to the feudal interpretation that was for a long time the default position.

${ }^{25}$ Both Anselm and Augustine use aesthetic metaphors in regard to hell, though readers often miss this, focusing too much on forensic metaphors. See David Brown, 'Anselm on Atonement,' in The Cambridge Companion to Anselm, ed. Brian Davies and Brian Leftow (Cambridge: Cambridge University Press, 2004); Frank Burch Brown, 'The Beauty of Hell: Anselm on God's Eternal Design,' Journal of Religion 73, no. 3 (1993); Stephen R. Holmes, 'The Upholding of Beauty: A Reading of Anselm's Cur Deus Homo,' Scottish Journal of Theology 54, no. 2 (2001); Hohyun Sohn, 'The Beauty of Hell? Augustine's Aesthetic Theodicy and Its Critics,' Theology Today 64(2007).

${ }^{26}$ Anselm, Cur Deus Homo (London: Griffith, Farran, Okeden \& Welsh, 1889), 1:21. 
Contrast this with an earlier passage, where Anselm describes the nature of our insult to God in a way that would seem to lead to a different conclusion. Recall Crisp's view that 'the dignity of God is infinite, so the seriousness of an offence committed against God is infinite. ${ }^{27}$ But according to Anselm, God's honour cannot be enhanced or debased. The real harm is not to God or God's honour, but in damage to the created world. If God ignored sin (neither punishing the sinner nor atoning by Christ's death), 'then in the universe (which God ought to order) there would occur a certain marring as a result of the violation of the order's beauty.' But this marring is of the world, not God. 'Therefore, it is evident that no one can honor or dishonour God as He is in Himself; but someone seems to do so. ${ }^{28}$ The universe is not of infinite value or honour or dignity, and so marring it is not worthy of infinite punishment. That is where Anselm's logic leads us, but he does not grant the conclusion.

\section{Hell Seems Cruel Because: The Victorians Were Soft on Crime}

The most interesting recent defence of hell's goodness is also the most clearly historicist. In fact, it ironically mirrors Shklar's historicist critique of hell. Just as she sees the invention of cruelty (and consequent rejection of hell) as moral progress, the following account sees the rejection of hell (and underlying invention of cruelty) as moral decline. There are frequent allusions to this argument in various critics of Talbott, Parry, and Bell, but the case is made especially clearly by R. Albert Mohler, who has been a prominent critic of Bell.

Mohler begins with a question that sounds like Shklar's. 'What has happened,' he asks, so that even those who formerly defended hell now entertain alternatives, like annihilationism, post-mortem repentance, and so on?

The answer must be found in understanding the impact of cultural trends and the prevailing worldview of Christian theology [since the Enlightenment]... There are particular doctrines that are especially odious and repulsive to the modern and postmodern mind. The traditional doctrine of hell as a place of everlasting punishment bears that scandal in a particular way. ${ }^{29}$

Mohler then answers his own question. Hell was widely affirmed by laity and clergy alike for over sixteen centuries. Doubters like Origen were few and far between. This changed beginning in the seventeenth century when 'various atheisms' and Socianianism emerged. ${ }^{30}$ For a time, these heretical views were kept in check by persecution, but the flowering of the Enlightenment set the stage for the real threat to hell: Victorian Christianity. Hell was already an embarrassment to 'decent and respectable' Victorians; the rise during the nineteenth century of scientific approaches to biblical criticism made it possible to ignore the embarrassment while remaining Christian. This was reinforced, says Mohler, by the 'Victorian cult of the family' in which the father 'would discipline his children, but never too severely... When this vision of fatherhood was extended to God, hell as eternal torment became unthinkable.' He concludes, 'As Gilbert and Sullivan put it to music in The Mikado, Victorians were insistent that "the punishment must fit the crime." Apparently, this argument was to become even more persuasive in the twentieth century. ${ }^{31}$

Thus far we have a narrative, but not an explanation. Avoiding the 'embarrassment' of hell becomes easier when the unorthodox are no longer persecuted. But what made it embarrassing in the first place? In the midst of some overly vague reasons ('the advent of the psychological worldview'?), Mohler presents one concrete claim: during the nineteenth

\footnotetext{
${ }^{27}$ Crisp, 'Divine Retribution,' 40.

${ }^{28}$ Anselm, Cur Deus Homo, 1:15.

${ }^{29}$ R. Albert Mohler, 'Modern Theology: The Disappearence of Hell,' in Hell under Fire : Modern Scholarship Reinvents Eternal Punishment, ed. Christopher W. Morgan and Robert A. Peterson (Grand Rapids: Zondervan, 2004), 36-37.

${ }^{30}$ Mohler, 'Disappearence of Hell,' 19.

${ }^{31}$ Mohler, 'Disappearence of Hell,' 24.
} 
century, an assault was launched against a retributive conception of justice by utilitarians such as John Stuart Mill and Jeremy Bentham. Retributive justice makes punishment central.

Punishment is an objective good because it rights a wrong. But for Bentham, 'all punishment in itself is evil' and only justified when it outweighs worse evils, for example by deterring crime or reforming the offender. ${ }^{32}$ Because an eternal hell admits no possibility of reform, it cannot be justified on this conception of justice.

Unsurprisingly, the true story of how criminal punishment changed between the early modern period and today is considerably more complicated. Doubts about the traditional conception of hell actually precede Bentham and emerge from within retributivism itself, especially from Christians who, for theologically orthodox reasons, sought to understand retributivism in light of the Christian gospel.

Central to Mohler's story is that we are unable to see hell's goodness because we are unable to see the good of retribution generally and this is because utilitarian or 'humanitarian' conceptions of punishment have captured our imagination. One recurring feature of this argument, in Mohler and others, is its dependence on a short essay by C.S. Lewis, 'The Humanitarian Theory of Punishment.' That essay is indeed a rebuttal to Benthamite theories of punishment, but its argument should provide little comfort to hell's defenders.

According to Bentham, punishment is justified only insofar as it deters other would-be criminals or reforms the offender. ${ }^{33}$ An eternal hell might do the former, but not the latter and so hell is unjust on this account of punishment. What this loses, says Lewis, is a sense of desert. A criminal deserves 'shame, exile, bondage, and years eaten by the locust,' even when these do not affect a change of heart. ${ }^{34}$ To this point, Mohler and Lewis agree. They both speak affectionately of 'the older view' of justice, in which retribution is central, and derisively of the newer view that replaces it. But here they part company. On a retributive theory of justice, which Mohler takes to be the Christian theory, hell is justified because the sinner deserves an eternity of torment. Retributivism makes harsher punishment possible than the utilitarian could allow.

But Lewis's argument runs exactly counter to this: only retributivism makes mercy possible. The problem with utilitarian punishment is that it has no limit. The 'humanity' of humanitarian punishment is a 'dangerous illusion,' for it 'disguises the possibility of cruelty and injustice without end.' Throughout the essay, all of Lewis's objections are to utilitarian punishment's lack of mercy, not to its lack of severity. He has in mind rehabilitationist 'treatment' programmes, in which a criminal is 'a mere object, a patient, a "case." Their goal is not righting wrongs, but curing - and the treatment for such cures may go on forever, 'cruelty without end.'

Thus the utilitarian view fails because it fails to be merciful. By replacing justice with mercy, it makes mercy impossible. 'The older view was that Mercy "tempered" Justice, or (on the highest level of all) that Mercy and Justice had met and kissed.' ${ }^{35}$ So the objections Lewis offers are effective against Bentham, but they will not help hell's defender. Of course, it should be no surprise that Lewis proves an unhelpful ally for hell's defenders, as his own occasional speculations on hell were hardly traditional. ${ }^{36}$

Mohler connects an embrace of utilitarian punishment to subsequent Victorian-era prison reforms, specifically mentioning the end to public executions and the U.S. Constitution's prohibition of cruel and unusual punishment. As he sees it, this is all part of

\footnotetext{
32 Jeremy Bentham, An Introduction to the Principles of Morals and Legislation (Oxford: Oxford University Press, 1996), 13:1.

${ }^{33}$ Bentham, An Introduction to the Principles of Morals and Legislation, ch. 14.

${ }^{34}$ C.S. Lewis, 'The Humanitarian Theory of Punishment,' Res Judicatae 6(1953): 227.

${ }^{35}$ Lewis, 'The Humanitarian Theory of Punishment,' 229.

${ }^{36}$ See C.S. Lewis, The Problem of Pain (London: HarperCollins, 2002), ch. 8; C.S. Lewis, The Great Divorce (New York: Simon \& Schuster, 1996).
} 
squeamishness toward the harsh reality of justice. If we can no longer perceive the goodness of public executions - in England, the practice ended in 1868 - it is no wonder that we fail to see the goodness of God punishing through hell. To be sure, Mohler's chronology here is somewhat muddled: the U.S. Constitution far precedes Victoria and, at any rate, 'cruel and unusual' is taken not from Bentham but from the even older English Bill of Rights of 1689. More problematic than the chronology, however, is that Victorian prison reform was itself largely a Christian movement, with support not only from theological liberals but also evangelicals like William Wilberforce. ${ }^{37}$

A careful, theological reading of early modern and Victorian debates on punishment shows that although there is a grain of truth to Mohler's argument, it is not a simple case of 'secular' mercy corrupting 'Christian' retributivism. The best theological accounts of these changes are Oliver O'Donovan's much subtler and richer analyses in Desire of the Nations and The Ways of Judgment. Recall that one of the more obvious flaws of Mohler's oversimplified story is that he cannot explain how the modern humanitarianism that he opposes emerges from its late medieval and early modern Christian ancestors. How did Christians come to find hell embarrassing in the first place? O'Donovan provides an explanation: the short answer is that classical political liberalism is itself a product of Christianity. It is Christendom's legacy for the modern world. But it becomes corrupted whenever it is severed from the theological framework that gave it birth. This is what happens in the case of modern views of punishment.

Even though later liberalism grew increasingly secular, its expectations of what good government looked like were originally shaped by the church. 'In tracing the characteristic features of liberal society, then, we need to show how it has been affected by the narrative structure of the church, which is itself a recapitulation of the narrative structure of the Christevent. ${ }^{38}$ O'Donovan mentions four aspects of liberal society shaped in this way: freedom, natural right, openness to speech and-most important for our purposes - mercy in judgment. ${ }^{39}$

The church is a suffering church, which the church expresses publically and politically as sympathy. 'Sympathy is the readiness to suffer with others and enter into the dark world of their griefs. " 40 ympathy is offered not only to the innocent who are judged wrongly (as was Christ) but even to those guilty who are rightly judged, for all Christian judgment is marked by a mercy in judgment. As we shall see, later liberals either conflate mercy with judgment (this was Lewis's critique of humanitarian punishment) or make them irretrievably opposed. In contrast, the Christian ideal insight has always been that mercy and justice will be brought together and interpenetrate. What this looks like in practice, O'Donovan concedes, is not easy to say. At most, human judgment can only point. 'When asked to say what that pointing might consist of, Christian thinkers could only reply that it involved the restraint of force to the minimum necessary.' The effect on Western civilization generally has been 'the elimination of anything that looked like extravagance in sanctions or penalties." ${ }^{\text {'1 }}$ This is because 'Christian liberalism taught judges to look over their shoulders when they pronounced on fellow-sinners' crimes. It taught them they were subject to the higher judgment of God, who would judge mercifully those that judged mercifully. ${ }^{, 42}$

It is actually from here - and not, as Shklar claims, from a rejection of religion - that we get our aversion to cruelty. As this commitment to merciful judgment is increasingly manifested in public, the horrors of hell depicted so vividly in Giotto's Last Judgment become

${ }^{37}$ Randall McGowen, 'Civilizing Punishment: The End of the Public Execution in England,' Journal of British Studies 33, no. 3 (1994): 263. See also Philip C. Almond, Heaven and Hell in Enlightenment England (Cambridge: Cambridge University Press, 2008); D.P. Walker, The Decline of Hell: 17th Century Discussions of Eternal Torment (Chicago: University of Chicago Press, 1964).

${ }^{38}$ Oliver O'Donovan, The Desire of the Nations (Cambridge: Cambridge University Press, 1996), 250.

${ }^{39}$ O'Donovan, Desire of the Nations, 270.

${ }^{40}$ O'Donovan, Desire of the Nations, 276.

${ }^{41}$ O'Donovan, Desire of the Nations, 260, emphasis added.

${ }^{42}$ O'Donovan, Desire of the Nations, 278. 
less and less comprehensible. But even if this concern for mercy tempering justice becomes more evident in modernity, it is not a modern innovation; it was there from the beginning. As O'Donovan shows, it is found in the Old Testament, the gospels, Paul, Augustine, and throughout church history.

So Christians were long committed to the view that punishment should be as merciful as possible without compromising justice, but what is (as O'Donovan puts it) 'the minimum necessary'? For much of church history, the minimum was thought to be quite high. For example, Augustine, with an air of reluctance, insists that judges are blameless and sinless for torturing the innocent, because this is required to preserve the well-ordered civil society during an era of sin and human wretchedness. ${ }^{43}$ It fell to Christian-inflected political liberalism to challenge this view by showing that a stable, ordered society was achievable even without a ruler possessing absolute power. The judicial harshness that accompanied absolutism was therefore unnecessary. The minimum necessary was in fact much lower.

It is no surprise that in in very short order, the Christian inclination to merciful judgment blossoms, freed of its mistaken dependence on absolutism and severe punishment. Consider the trajectory from seventeenth century England to the present day. The English Bill of Rights of 1689 prohibits cruel and unusual punishment but among the penalties still permitted at that time, and thus not considered cruel, were mutilation, burning at the stake, and being disembowelled alive, with the victim's intestines burnt before him. Yet also in 1689 the most influential defence of classical political liberalism appears in John Locke's Two Treatises of Government and his Letter Concerning Toleration. Soon thereafter the scope of punishments considered cruel, and thus impermissible, greatly expands. In 1790, the burning alive of women (for whom it had been the traditional penalty) is repealed in England. Less than a century later, largely under pressure from Christian social reformers, public executions were ended, and capital punishment itself was abolished in England in 1965. We thus see merciful punishment as a Christian cause. Retributive justice is not the enemy of mercy, but (if it is Christian) is transformed by mercy. ${ }^{44}$

The problem this poses for Mohler can be captured by recalling his remark, which he intends to be critical, that "Victorians were insistent that "the punishment must fit the crime." ${ }^{45}$ But surely the Victorians were right; punishments should fit crimes. And if they were insistent on this, then a retributivist like Mohler should applaud. What Mohler actually seems to object to is the growing sensibility by which public hangings came to be seen as ugly affairs and torture or maiming were now unfitting. These terms betray that these are aesthetic judgments, in the sense of mores or manners, rather than geometric deductions. It is similar to the judgment that it would be bad taste to have sex on the table of a crowded restaurant. Mohler is correct: these particular aesthetic sensibilities do become especially prominent in the nineteenth century. More to the point, they do get in the way of hell. If I believed that publically burning or disembowelling was a good or praiseworthy demonstration of the king's justice and necessary to preserve civil order, then I can likely see God's actions as similarly fitting and necessary.

On all of this, Mohler is ironically in firm agreement with Shklar-as well as Lewis and O'Donovan. But what he cannot provide is a theory of justice that make it possible to praise God's actions in hell, or way to foster the associated habits of mind that would make such an account plausible. Instead his reasoning ends in a voluntarist retreat: defending hell's goodness is unnecessary, even superfluous. Contrast this with C.S. Lewis who steadfastly resists such a retreat: 'There is no doctrine that I would more willingly remove from Christianity than this... [Yet] it has the support of reason... [and] the doctrine can be shown to

\footnotetext{
${ }^{43}$ Augustine, City of God, 19:6.

${ }^{44}$ O'Donovan is especially clear in showing how this happens in Grotius's thought. Oliver O'Donovan,
} The Ways of Judgment (Grand Rapids: Eerdmans, 2005), ch. 7.

${ }^{45}$ Mohler, 'Disappearence of Hell,' 24. 
be moral. ${ }^{46}$ For all the cleverness of Mohler's historical narrative, he does not take seriously the problem that the New Universalists identify: to worship a God who punishes requires an account of justice showing that this punishment fits that crime.

\section{Conclusion}

I suggested at the outset that my short-term goal was to evaluate accounts of hell that defend its goodness and that, if these defences were unsatisfactory, our long-term goal should be to seek either better moral theories or better conceptions of hell. The three defences that I evaluated are indeed unsatisfactory. What then of the longer term task? I can offer only a brief gesture, in what I hope is the right direction, by proposing two future conversations on the topic.

As for better moral theories, I have not heard of any others to justify an Augustinian hell, nor can I think of one myself. However there are alternative conceptions of hell for which there are viable moral theories. Of the four features of an Augustinian hell identified above, it is the penal element that may be the most problematic; the idea that what happens in hell is an extrinsic to the offender's wrongdoing and is imposed in the same way that a judge imposes a sentence. The alternative is excellently presented by Eleonore Stump, who shows the difference than a non-penal conception of hell would make and how, under a Thomistic moral theory, such a hell is good and worthy of honour. ${ }^{47}$ It may be that the best alternatives lie in this direction. Certainly the most interesting future conversations will lie between advocates of such approaches and perspectives like the New Universalism.

There is another conversation to be had, however, with different interlocutors. Some may reject my whole argument because they deny a premise I have assumed throughout: that an adequate defence of hell demands a moral theory on which it could be seen as just. Some do not mind if God seems cruel and are comfortable holding goodness alongside an apparent injustice. Thus John Piper writes that if God eternally torments Piper's children because it suits God's pleasure, 'I would not rail against the Almighty... The potter has absolute rights over the clay. ${ }^{48}$ To this we must ask, what does it mean to praise God's attributes while simultaneously conceding that you cannot perceive God's goodness?

Or consider a recent op-ed in The Christian Post criticizing one scholar's account of hell as too weak: 'If I could snap my fingers and make N.T. Wright's version of hell become the real one, I would do it. ${ }^{49}$ Can we imagine saying this about other doctrines? ('I wish that Gunton's view of the Trinity were correct. I would even change the Trinity to make it fit Gunton if I could, because that would be a much better Trinity than the true one. But never mind.') Would that even make sense? What is needed, then, is much greater analytic clarity on statements of the form believe $x$ but want $y$. What does it mean to conclude (on theological grounds) that doctrine $x$ is true but to want (presumably also on theological grounds) doctrine $y$ to be true?

\footnotetext{
${ }^{46}$ Lewis, The Problem of Pain, 119-121, emphasis added. The moral hell that Lewis defends is not Augustine's; rather, he weakens it in various ways, especially by removing the penal element.

${ }^{47}$ Eleonore Stump, 'Dante's Hell, Aquinas's Moral Theory, and the Love of God,' Canadian Journal of Philosophy 16, no. 2 (1986). A similar view is suggested in Finnis, 'Hell and Hope,' 370.

48 John Piper, 'How Does a Sovereign God Love? A Reply to Thomas Talbott,' The Reformed Journal 33, no. 4 (1983): 13.

${ }^{49}$ Dan Delzell, 'N.T. Wright Wrong About Eternal Torment?,' The Christian Post, December 22, 2012 2012.
} 